\title{
Memasyarakatkan "Tanya 5 0" dan Efek Interaksi Obat pada Siswa MTsN 2 Kota Palangka Raya
}

\author{
Harlyanti Muthma'innah Mashar ${ }^{1 *}$, Normila1 ${ }^{1}$, Juni Ramadhani ${ }^{1}$, Dali $^{2}$, Ismail ${ }^{3}$ \\ ${ }^{1}$ Jurusan Gizi, Poltekkes Kemenkes Palangka Raya \\ 2Jurusan Keperawatan, Poltekkes Kemenkes Kendari \\ ${ }^{3}$ Sekolah Tinggi Ilmu Farmasi Makassar
}

\begin{abstract}
ABSTRAK
Pengabdian masyarakat ini merupakan salah satu bentuk sharing program kerjasama dari Kementerian Kesehatan RI dan Dinas Kesehatan Provinsi dan Kota yaitu GeMa CerMat (Gerakan Masyarakat Cerdas Menggunakan Obat) yang salah satu programnya adalah melalui promosi tagline "Tanya Lima 0". Melalui tagline ini diharapkan masyarakat dapat lebih aktif lagi dalam mencari informasi tentang obat, tidak hanya pada tenaga kesehatan, namun juga dapat diperoleh dari sumber lain yang valid dan dapat dipercaya. Selain informasi tersebut, masyarakat juga perlu mengetahui interaksi obat, khususnya interaksi obat dengan makanan. Demi tercapainya penggunaan obat yang bermutu dan aman, keterlibatan masyarakat secara aktif sangat diharapkan. Pada kegiatan ini yang menjadi target sasaran adalah siswa di MTsN 2 Palangka Raya. Metodenya berupa pelaksanaan posttest dan pretest, penyuluhan interaktif dengan para peserta, diskusi dan tanya jawab. Nilai yang didapatkan dari hasil posttest dan pretest kemudian dilakukan uji statistik menggunakan paired T-test dan uji Gain. Berdasarkan hasil analisis diperoleh hasil bahwa terdapat perbedaan pengetahuan yang bermakna antara sebelum dan sesudah penyuluhan diberikan. Hal ini dibuktikan dengan terjadinya peningkatan nilai posttest. Rata-rata nilai posttest adalah 80 , dan nilai ini lebih besar dari pada nilai rata-rata pretest yaitu 44. Hasil analisis dengan paired $T$-test diperoleh nilai $\mathrm{p}=0,000$ yang menunjukkan bahwa terdapat perbedaan pengetahuan yang bermakna antara sebelum dengan sesudah penyuluhan. Nilai pemahaman yang meningkat setelah diberikan penyuluhan ditunjukkan dengan persentase $87,69 \%$, terdiri dari yang memperoleh nilai Gain tinggi sebanyak 25 orang (38,46\%) dan sedang sebanyak 32 orang $(49,23 \%)$.

Kata kunci: GeMa CerMat, Tanya Lima O, interaksi obat
\end{abstract}

\section{Promoting "Tanya 5 0" and Effects of Drugs on Nutritional Status in Students of MTsN 2 Palangka Raya}

\begin{abstract}
This community service is a form of sharing program of cooperation between the Indonesian Ministry of Health and the Provincial and City Health Offices, namely GeMa CerMat (Smart Community Movement Using Drugs), one of which is through the promotion of the tagline "Tanya Lima 0". Through this tagline, it is hoped that the public can be more active in seeking information about drugs, not only for health workers but also from other valid and trustworthy sources. Apart from this information, people also need to know drug interactions, especially drug interactions with food. To achieve quality and safe drug use, active community involvement is highly expected. In this activity, the target audience is students at MTsN 2 Palangka Raya. The method is in the form of the posttest and pretest implementation, interactive counseling with participants, discussion, and question and answer. The value obtained from the posttest and pretest results was then performed statistical tests using the paired T-test and the Gain test. Based on the results of the analysis, it was found that there was a significant difference in knowledge between before and after counseling was given. This is evidenced by the increase in posttest scores. The average posttest score was 80 , and this value was greater than the pretest average score of 44 . The results of the analysis with the paired T-test obtained $p$-value $=0.000$, indicating a significant difference in knowledge between before and after counseling. The value of understanding that increased after being given counseling was shown by a percentage of $87.69 \%$, consisting of 25 people (38.46\%) who obtained high Gain values and 32 people $(49.23 \%)$.
\end{abstract}

Keywords: GeMa CerMat, Tanya 5 O, drug interactions

\section{Penulis Korespondensi :}

Harlyanti Muthma'innah Mashar, Jurusan Gizi, Poltekkes Kemenkes Palangka Raya

E-mail : harlyanti@poltekkes-palangkaraya.ac.id

No. Hp : 085241687055 


\section{PENDAHULUAN}

Kejadian salah pengobatan seringkali terjadi pada masyarakat disebabkan karena kurang mendapatkan informasi terkait penggunaan obat yang tepat. Dewasa ini, masyarakat sudah mulai berupaya untuk memberikan pengobatan terhadap dirinya sendiri. Upaya ini biasanya disebut dengan swamedikasi. Swamedikasi merupakan suatu upaya yang dilakukan individu dengan memilih dan menggunakan obat untuk mengobati penyakit atau gejela suatu penyakit. Swamedikasi menjadi pilihan awal masyarakat untuk menanggulangi gejala atau keluhan penyakit sebelum ke pelayanan kesehatan. Masyarakat melakukan swamedikasi bertujuan untuk mengatasi masalah kesehatan yang mereka alami. Jika dilakukan dengan tepat dan benar, maka swamedikasi dapat meningkatkan pemeliharaan kesehatan dan keterjangkauan pengobatan. Namun, swamedikasi juga dapat memberikan dampak negatif berupa timbulnya permasalahan kesehatan yang dapat berakibat timbulnya penyakit baru, efek yang diinginkan tidak tercapai, timbul efek samping yang tidak diinginkan, dan overdosis. Akibatnya, swamedikasi dapat menjadi sumber terjadinya kesalahan dalam pengobatan. Kesalahan ini seringkali terjadi akibat kurangnya informasi tentang cara penggunaan obat yang tepat (Aswad, Kharisma, Andriane, Respati, \& Nurhayati, 2019; Supardi, Susyanti, \& Herdarwan, 2019; Tuarissa, 2014).

Pendekatan secara promotif dalam upaya untuk melakukan pengobatan sendiri termasuk dalam sistem kesehatan yang dilaksanakan pada beberapa negara di Eropa. Faktor sosial menjadi pertimbangan masyarakat untuk melakukan pengobatan sendiri karena dapat meningkatkan jangkauan masyarakat akan pelayanan kesehatan (Andarmoyo, 2013; Supardi et al., 2019). Dalam hal ini, masyarakat memiliki peluang untuk dapat berperan dalam mewujudkan perlindungan diri dari berbagai dampak negatif yang dapat timbul akibat penggunaan obat yang tidak tepat atau tidak memenuhi persyaratan. Penyampaian informasi dan penyebarluasan terkait hal tersebut sangat perlu dilakukan dalam rangka meningkatkan dan mendayagunakan kemampuan yang dimiliki masyarakat dalam rangka penggunaan obat yang rasional. Hal ini juga dapat digunakan untuk meningkatkan peran serta masyarakat (Supardi, Handayani, Herman, Raharni, \& Susyanty, 2012; Supardi et al., 2019).

Masih kurangnya pengetahuan masyarakat tentang penggunaan obat yang tepat tentu saja memerlukan adanya peran serta dan kerjasama dari pemerintah pusat, daerah, dan masyarakat untuk melaksanakan kegiatan dalam rangka meningkatkan pengetahuan, pemahaman, dan kesadaran dalam menggunakan obat dengan baik (Suryani, Fitrawan, Arsyad, Andriani, \& Hamsidi, 2020). Pemerintah pusat, dalam hal ini Kementerian Kesehatan, telah bekerja sama dengan Dinas Kesehatan di provinsi dan kota saat ini semakin gencar melaksanakan program GeMa Cermat. GeMa Cermat 
merupakan suatu gerakan yang bertujuan untuk meningkatkan pengetahuan, pemahaman, dan kesadaran akan penggunaan obat secara baik dan benar (Musdalipah, 2018; Suryani et al., 2020).

Berbagai upaya telah dilakukan untuk meningkatkan kesadaran masyarakat akan kesehatan, termasuk melalui penyebaran informasi pada berbagai media. Penyebarluasan informasi melalui penyuluhan dan pemberdayaan masyarakat terkait GeMa Cermat diharapkan mampu meningkatkan penggunaan obat rasional pada masyarakat. Hal lain yang perlu diketahui adalah melalui GeMa Cermat maka dapat meningkatkan kemandirian masyarakat sehingga dapat memilih, memperoleh, menggunakan, menyimpan, dan memusnahkan obat secara baik dan benar sehingga penggunaan obat secara rasional $\mathrm{di}$ masyarakat dapat mengalami peningkatan (Kemenkes, 2015; Musdalipah, 2018). Salah satu program dalam GeMa CerMat adalah melalui promosi dengan tagline "Tanya 5 0". “Tanya 5 0" merupakan 5 (lima) pertanyaan minimal yang harus terjawab sebelum mengonsumsi obat, yaitu: (1) Obat ini apa nama dan kandungannya?; (2) Obat ini apa khasiat/indikasinya?; (3) Obat ini berapa dosisnya? (4) Obat ini bagaimana cara menggunakannya?; dan (5) Obat ini apa efek sampingnya?. Melalui tagline ini diharapkan masyarakat dapat lebih aktif dalam mencari informasi tentang obat, dari sumber informasi yang valid dan terpercaya.
Selain informasi tersebut, masyarakat juga perlu mengetahui interaksi obat, khususnya interaksi obat dengan makanan. Interaksi obat dapat memberikan pengaruh berupa peningkatan efek obat atau sebaliknya malah dapat menurunkan efek obat. Terjadinya perubahan efek obat tersebut untuk masing-masing individu sangat bervariasi. Hal ini disebabkan karena berbagai faktor seperti dosis, konsentrasi obat dalam darah, rute pemberian, proses metabolisme, lama penggunaan, dan kondisi pasien. Interaksi obat tidak semua memberikan efek yang signifikan bagi tubuh, namun bisa menjadi berbahaya pada kondisikondisi tertentu. Masyarakat tentunya harus waspada akan kemungkinan timbulnya efek yang tidak diinginkan akibat interaksi obat (Alifiar, 2016). Demi tercapainya penggunaan obat yang bermutu dan aman, keterlibatan masyarakat secara aktif sangat diharapkan.

Usia anak dan remaja merupakan usia pada saat melaksanakan masa belajar di sekolah. Pada usia ini seringkali anak dan remaja menerima praktek swamedikasi. Sekitar $40 \%$ anak dan remaja setidaknya pernah menerima satu produk medis yang diresepkan dalam satu tahun. Pada umumnya, anak dan remaja sudah mengenali penyakit dan bentuk pengobatannya. Hal ini menyebabkan anak dan remaja dapat berperan aktif dalam penggunaan obat. Namun, pengetahuan anak dan remaja terkait penggunaan obat dan interaksinya dengan makanan yang dikonsumsi masih sangat terbatas sehingga dapat 
rentan terhadap masalah yang ditimbulkan akibat penggunaan obat (Syofyan, Ghiffari, \& Zaini, 2017). Melalui kegiatan ini diharapkan dapat meningkatkan pengetahuan untuk memperoleh informasi tentang obat dan efek yang timbul jika terjadi interaksi obat dengan makanan di dalam tubuh.

\section{METODE}

Kegiatan pengabdian kepada masyarakat ini berupa penyuluhan interaktif yang dilaksanakan di MTsN 2 Kota Palangka Raya. Kegiatan ini terbagi dalam 3 tahap yaitu:

1. Tahap persiapan

a. Pemantapan sasaran

b. Penyusunan bahan atau materi kegiatan

c. Persiapan pelaksanaan kegiatan

2. Tahap Pelaksanaan Kegiatan

Penjelasan tentang kegiatan yang dilaksanakan, kemudian dilanjutkan dengan penyuluhan interaktif serta diskusi dan tanya jawab.

3. Tahap Evaluasi

Evaluasi yang dilakukan yaitu dengan memberikan posttest dan pretest kepada peserta terhadap materi yang disampaikan dengan indikator keberhasilannya yaitu lebih dari 75\% peserta penyuluhan dapat memahami materi yang diberikan.

Populasi dalam kegiatan ini adalah seluruh siswa MTsN 2 Kota Palangka Raya. Peneliti melibatkan peserta sebanyak 65 orang siswa yang berasal dari 2 kelas. Tehnik pengambilan sampel adalah dengan metode accidental sampling. Data yang digunakan merupakan data primer yang dikumpulkan dengan melakukan pengisian kuesioner. Analisis yang digunakan dalam kegiatan ini adalah paired T-test dan uji Gain.

\section{HASIL DAN PEMBAHASAN}

Pengabdian masyarakat ini merupakan salah satu bentuk sharing program antara Kementerian Kesehatan dan Dinas Kesehatan Provinsi Kota yaitu GeMa Cermat. Untuk melakukan promosi GeMa Cermat berbagai upaya telah dilakukan, antara lain penyebaran informasi melalui berbagai media. Salah satu program dalam GeMa CerMat adalah mempromosikan tagline "Tanya Lima 0". Kegiatan ini bertujuan untuk meningkatkan pengetahuan dalam memperoleh informasi tentang obat dan mengenai efek yang terjadi jika penggunaan obat tertentu dilakukan bersamaan dengan bahan nutrisi yang bersumber dari makanan bagi siswadi MTsN 2 Kota Palangka Raya. 


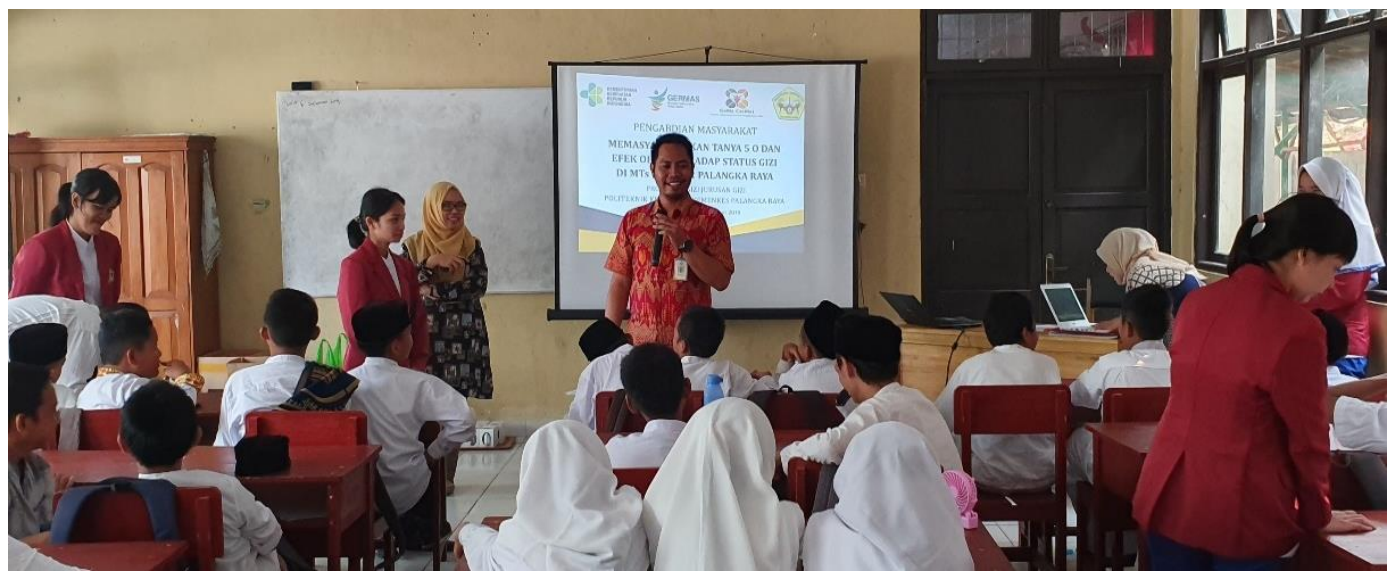

Gambar 1. Kegiatan Penyuluhan Tanya 50 dan Efek Interaksi Obat

Pada kegiatan ini yang menjadi target sasaran adalah siswa di MTsN 2 Palangka Raya, Kalimantan Tengah. Metodenya berupa penyuluhan interaktif dengan para siswa kemudian diskusi dan tanya jawab. Sebelum melaksanakan penyuluhan terlebih dahulu dilakukan pretest kepada para siswa untuk melihat sejauh mana pemahaman mereka tentang Tanya 50 dan efek interaksi obat. Setelah melaksanakan penyuluhan dilakukan postest yang akan dibandingkan dengan hasil pretest untuk melihat peningkatan pemahaman mereka setelah dilakukan penyuluhan. Berdasarkan tes tersebut maka diperoleh hasil nilai dari para siswa setelah menjawab soal tes yang diberikan. Nilai tersebut kemudian diuji secara statistik menggunakan paired $T$ test. Tingkat pengetahuan dapat dikategorikan menjadi 3 yaitu kategori pengetahuan Baik jika nilainya $\geq 76-100$, kategori pengetahuan Cukup jika nilainya 60-75 dan kategori pengetahuan Kurang jika nilainya $<60$.

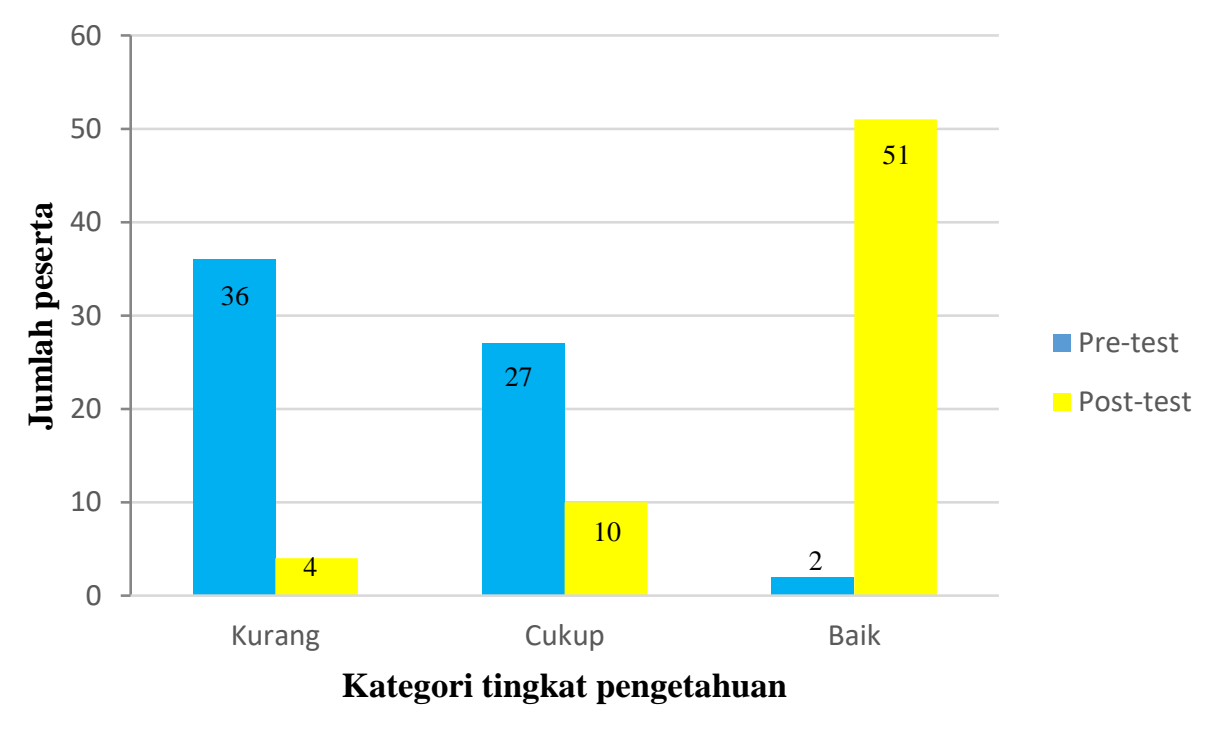

Gambar 2. Grafik Perbedaan Tingkat Pengetahuan Siswa Sebelum dan Setelah Penyuluhan 
Rerata nilai peserta pada saat pretest yaitu 44 , sedangkan rerata nilai peserta pada saat posttest 80 . Berdasarkan hasil analisis dengan paired T-test diketahui bahwa nilai $\mathrm{p}=0,000 \quad(\mathrm{p}<0,05) \quad$ jadi dapat disimpulkan bahwa terdapat perbedaan pengetahuan yang bermakna sebelum dan sesudah penyuluhan. Sehingga secara keseluruhan terjadi peningkatan pengetahuan pada para siswa tersebut dibuktikan dengan nilai posttest sebanyak 51 peserta $(78,46 \%)$ telah memiliki tingkat pengetahuan baik dan dapat memahami materi yang telah diberikan. Sehingga, kegiatan ini mencapai indikator keberhasilan yaitu lebih dari $75 \%$ peserta penyuluhan dapat memahami materi yang diberikan (Gambar 1).

Uji Gain merupakan hasil selisih antara nilai pada saat postest dan pretest. Gain menunjukkan adanya peningkatan pemahaman konsep siswa setelah diberikan penyuluhan. Gain ternormalisasi ( $\mathrm{N}$ gain) dapat didapatkan melalui perhitungan selisih antara skor postest dan pretest kemudian dibagi dengan selisih antara skor maksimal dengan skor tes awal. Tingkat perolehan gain ternormalisasi dibagi menjadi 3 kategori yaitu tinggi jika N- Gain $>0,70$, sedang jika 0,3 $<\mathrm{N}$ Gain $<0,70$, dan rendah jika $<0,3$.

Gain normalisasi ( $\mathrm{N}$ gain $)=$ $\frac{\text { skor test akhir-skor test awal }}{\text { skor maksimal-skor test awal }}$

Berdasarkan hasil perhitungan yang dilakukan, diketahui bahwa untuk kategori nilai gain rendah sebanyak 8 orang $(12,31 \%)$, nilai gain sedang sebanyak 32 orang $(49,23 \%)$ dan nilai gain tinggi sebanyak 25 orang $(38,46 \%)$. Berdasarkan hasil tersebut menunjukkan nilai pemahaman yang meningkat setelah diberikan penyuluhan, meskipun masih ada 8 orang siswa(i) yang memiliki kategori nilai gain rendah.

Rerata pengetahuan peserta meningkat dari 44 menjadi 80 . Hal ini menunjukkan bahwa penyuluhan yang dilakukan terbukti efektif untuk meningkatkan pengetahuan peserta. Berbagai penelitian menunjukkan terdapat perbedaan yang signifikan terhadap pengetahuan sebelum dan setelah diberikan penyuluhan (Aritonang, 2018; Aritonang, Nugraeny, Sumiatik, \& Siregar, 2020).

Pengetahuan atau kognitif merupakan domain yang sangat penting dalam membentuk perilaku seseorang (Aritonang, 2018). Kurangnya pengetahuan tentang penggunaan obat dan interaksinya dengan makanan yang dikonsumsi dapat meningkatkan kerentanan terhadap masalah yang ditimbulkan akibat penggunaan obat (Syofyan et al., 2017). Melalui kegiatan penyuluhan dalam rangka peningkatan pengetahuan diharapkan dapat memberikan pengaruh terhadap perilaku. Perilaku yang didasari oleh adanya pengetahuan akan dapat lebih konsisten untuk dilaksanakan dibandingkan perilaku yang tidak didasari oleh pengetahuan (Aritonang, 2018).

Penyuluhan dapat memberikan pengaruh pada peningkatan pengetahuan, baik kepada individu ataupun kelompok. Adanya media yang digunakan untuk mendukung 
pelaksanaan kegiatan penyuluhan merupakan salah satu komponen terpenting dalam kegiatan (Johariyah \& Mariati, 2018). Dalam kegiatan pengabdian masyarakat dilaksanakan penyuluhan dengan metode ceramah menggunakan alat bantu media power point. Melalui media power point dapat membantu untuk memperjelas dalam penyampaian pesan atau informasi yang kadang kala ketika hanya disampaikan secara lisan tidak dapat dipahami secara utuh.

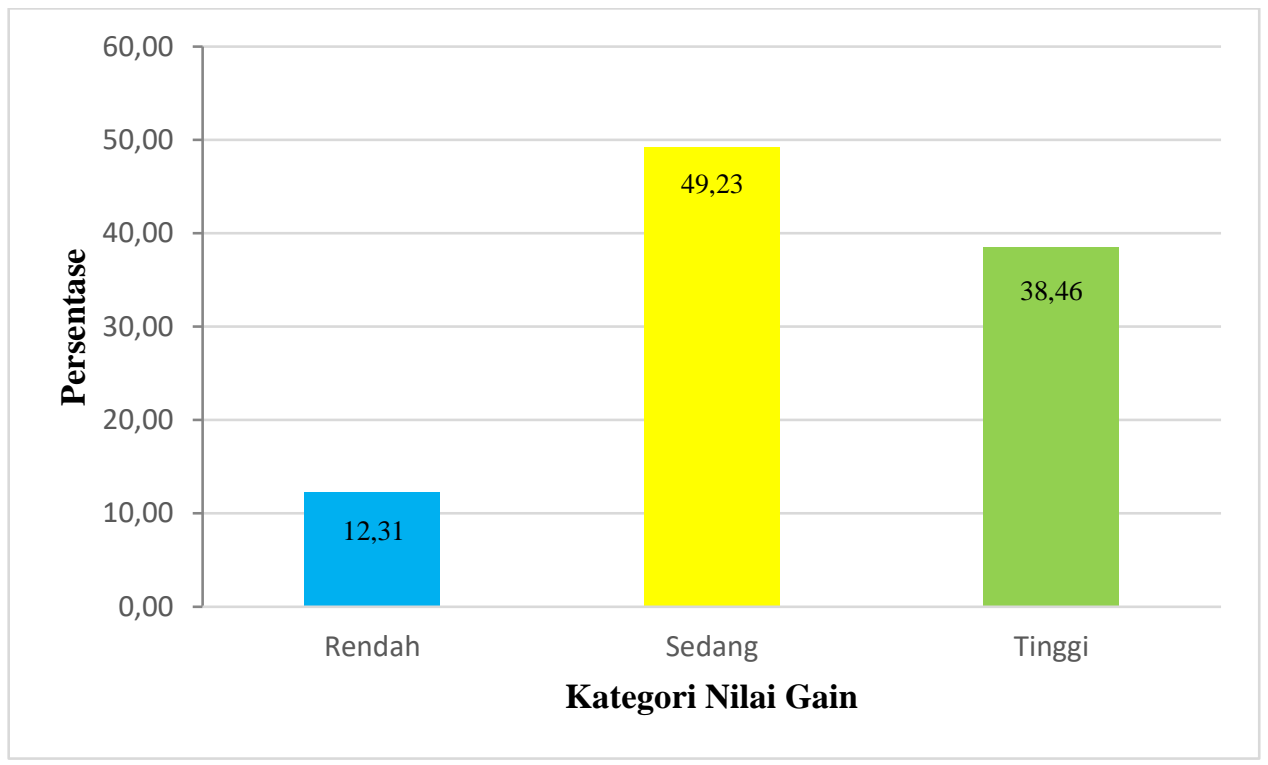

Gambar 3. Grafik \% Kategori Nilai Gain

\section{KESIMPULAN}

1. Ada perbedaan pengetahuan yang bermakna antara sebelum dan sesudah penyuluhan $(p=0,000)$.

2. Nilai pemahaman yang meningkat setelah diberikan penyuluhan ditunjukkan dengan persentase 87,69\%, terdiri dari yang memperoleh nilai Gain tinggi sebanyak 25 orang $(38,46 \%)$ dan nilai Gain sedang sebanyak 32 orang $(49,23 \%)$.

\section{UCAPAN TERIMA KASIH}

Ucapan terimakasih ditujukan kepada Poltekkes Kemenkes Palangka Raya dan Jurusan Gizi yang telah memberikan kesempatan bagi kami untuk melaksanakan kegiatan pengabdian kepada masyarakat, serta kepada seluruh pihak yang telah membantu dalam pelaksanaan kegiatan ini.

\section{DAFTAR PUSTAKA}

Alifiar, I. (2016). Gambaran Potensi Interaksi Obat dengan Makanan pada Pasien Hepar yang Dirawat di Sebuah Rumah Sakit di Kota Tasikmalaya. Jurnal Surya Medika, 2(1), 4752. https://doi.org/10.33084/jsm.v2i1.374

Andarmoyo, S. (2013). Konsep \& proses keperawatan nyeri. Yogyakarta: Ar-Ruzz Media.

Aritonang, J. (2018). Peningkatan Pengetahuan Ibu Tentang Imunisasi Pentabio Lanjutan Setelah Pemberian Pendidikan Kesehatan di Puskesmas Lampaseh Aceh. Jurnal Riset Kesehatan Nasional, 2(2), 173. https://doi.org/10.37294/jrkn.v2i2.125 
Aritonang, J., Nugraeny, L., Sumiatik, \& Siregar, R. N. (2020). Peningkatan Pemahaman Kesehatan pada Ibu hamil dalam Upaya Pencegahan COVID-19. Jurnal SOLMA, 9(2), 261-269.

https://doi.org/10.22236/solma.v9i2.5522

Aswad, P. A., Kharisma, Y., Andriane, Y., Respati, T., \& Nurhayati, E. (2019). Pengetahuan dan Perilaku Swamedikasi oleh Ibu-lbu di Kelurahan Tamansari Kota Bandung. Jurnal Integrasi Kesehatan \& Sains, 1(2), 107-113. https://doi.org/10.29313/jiks.v1i2.4462

Johariyah, A., \& Mariati, T. (2018). Efektivitas Penyuluhan Kesehatan Reproduksi Remaja Dengan Pemberian Modul Terhadap Perubahan Pengetahuan Remaja. Jurnal Manajemen Kesehatan Yayasan RS.Dr. Soetomo, 4(1), 38. https://doi.org/10.29241/jmk.v4i1.100

Kemenkes. (2015). Keputusan Menteri Kesehatan Nomor 427 Tahun 2015 tentang Gerakan Masyarakat Cerdas Menggunakan Obat. Jakarta: Sekretariat Negara.

Musdalipah, M. (2018). Pemberdayaan Masyarakat Tentang Swamedikasi Melalui Edukasi Gema Cermat Dengan Metode CBIA. Dinamisia: Jurnal Pengabdian Kepada Masyarakat, 2(1), 106-112.

https://doi.org/10.31849/dinamisia.v2i1.108 5

Supardi, S., Handayani, R. S., Herman, M. J., Raharni, R., \& Susyanty, A. L. (2012). Kajian Peraturan Perundang-undangan tentang
Pemberian Informasi Obat dan Obat Tradisional di Indonesia. Jurnal Kefarmasian Indonesia, 2(1), 20-27. https://doi.org/10.22435/JKI.V2I1.4040.2027

Supardi, S., Susyanti, A. L., \& Herdarwan, H. (2019). Kajian Kebijakan tentang Informasi dan Pelayanan Obat yang Mendukung Pengobatan Sendiri di Masyarakat. Media Penelitian Dan Pengembangan Kesehatan, 29(2), 161-170. https://doi.org/10.22435/mpk.v29i2.481

Suryani, S., Fitrawan, L. O. ., Arsyad, W. S., Andriani, R., \& Hamsidi, R. (2020). Gema Cermat (Gerakan Masyarakat Cerdas Menggunakan Obat) For Student In The City Of Kendari Southeast Sulawesi. Darmabakti Cendekia: Journal of Community Service and Engagements, 2(1), 4. https://doi.org/10.20473/dc.v2.i1.2020.4-8

Syofyan, S., Ghiffari, H. D., \& Zaini, E. (2017). Persepsi, Pengetahuan, dan Sikap tentang Obat pada Siswa Sekolah Menengah Atas (SMA) di Kota Pariaman, Sumatera Barat. Jurnal Sains Farmasi \& Klinis, 4(1), 83. https://doi.org/10.29208/jsfk.2017.4.1.202

Tuarissa, S. (2014). Profil Penggunaan Obat Klorfeniramin Maleat pada Masyarakat di Kelurahan Bailang dan Kelurahan Karombasan Kota Manado. PHARMACON, 3(4).

https://doi.org/10.35799/PHA.3.2014.6042 